\title{
Phytoremediation of Palm Oil Mill Effluent (POME) Using Eichhornia crassipes
}

\author{
Ivy Ai Wei Tan ${ }^{\mathrm{a}, *}$, Nur Syakina Jamali ${ }^{\mathrm{b}}$ and Winnie Huong Tien Ting ${ }^{\mathrm{a}}$ \\ ${ }^{a}$ Department of Chemical Engineering and Energy Sustainability, Faculty of Engineering, \\ Universiti Malaysia Sarawak, 94300 Kota Samarahan, Sarawak, Malaysia \\ ${ }^{b}$ Department of Chemical and Environmental Engineering, Faculty of Engineering, \\ Universiti Putra Malaysia, 43400 UPM Serdang, Selangor, Malaysia
}

\begin{abstract}
The inefficiency and lengthy treatment process of conventional open ponding method has posed challenges to palm oil industry in treating highly polluting palm oil mill effluent (POME), thus there is a need to look for a more efficient and sustainable alternative solution. Phytoremediation has been recommended as a potential method for wastewater treatment due to its economical and environmental advantages. However, research on phytoremediation of POME using Eichhornia crassipes (E. crassipes) is still limited. This study aims to determine the feasibility of applying phytoremediation using E. crassipes for POME treatment by investigating the effects of $p H$, plant:POME ratio and retention time on the biochemical oxygen demand (BOD), chemical oxygen demand (COD) and total suspended solid (TSS) in POME. The highest BOD removal of $92.78 \%$ was achieved after 21 days retention time at $\mathrm{pH} 4$ with plant:POME ratio of 1:20 $\mathrm{kg} / \mathrm{L}$. The highest $C O D$ removal of 25.24\% was achieved after 14 days retention time at $\mathrm{pH} 6$ with plant:POME ratio of 1:20 $\mathrm{kg} / \mathrm{L}$. Phytoremediation using E. crassipes was shown to be a promising eco-friendly technique for POME treatment, considering the shorter treatment time required and its effectiveness in reducing the $B O D$ in POME to meet the discharge standard of $20 \mathrm{mg} / \mathrm{L}$.
\end{abstract}

Keywords: Phytotechnology; Water hyacinth; Palm oil mill effluent (POME); Wastewater treatment.

\section{Introduction}

High global demand of edible oil has led to the rapid growth and development of palm oil industry [1]. As the second largest global palm oil producer, Malaysia also plays significant role as the worldwide supplier of palm oil, which accounts for about $39 \%$ of world palm oil manufacturing and $44 \%$ of worldwide exports [2,3]. During crude palm oil manufacturing process, the generation of vast volume of highly polluting palm oil mill effluent (POME) poses challenges to the wastewater treatment of palm oil industry. In order to process one ton of crude palm oil, it requires approximately 5-7.5 tons of water input, however, over half of this water volume would turn out to be wastewater [4]. Liquid effluent is mostly formed from the sterilization and clarification processes in palm oil mill where huge amount of hot water, saturated as well as superheated steam are being used. Hydrocyclone operation is a process where the broken shells are separated from the kernels resulting in another source of waste. POME is formed from the mixing between both effluents [5]. It is a common

\footnotetext{
* Corresponding author. Tel.: +6082 583312; Fax: +6082 583410

E-mail address: awitan@unimas.my

Manuscript History:

Received $28^{\text {th }}$ September, 2018, Revised $15^{\text {th }}$ March 2019, Accepted $28^{\text {th }}$ March, 2019, Published $31^{\text {st }}$ March, 2019
} 
liquid waste that is being produced in palm oil mill through oil clarification, cleaning and washing processes. POME is characterized as a thick brownish liquid with unpleasant odor and rich in organic matter [6]. This high strength wastewater will cause harmful effects to the groundwater, soil and atmosphere if not treated properly before being discharged into watercourses, due to its high organic load, oil and grease content [7]. In terms of biological oxygen demand (BOD), POME is hundred times more contaminating than the residential sewage [8].

In Malaysia, open ponding is the popular POME treatment method utilized by most of the palm oil mills which involves aerobic or anaerobic processes. The operating of POME treatment processes usually consists of two stages, the first is two-phase anaerobic digestion process, then followed by the second stage, which is extended aeration process. However, ponding system possesses numerous drawbacks, such as requirement of lengthy hydraulic retention time and spacious land area, and the treated effluent frequently fails to comply with the discharge standards set by the Department of Environment Malaysia (DOE) [9]. Open ponding has also become less attractive due to the contribution of greenhouse gases (i.e. carbon dioxide, methane gas) to the surrounding atmosphere [10]. Besides, this system cannot be approved for Carbon Emission Reduction trading [11]. In order to overcome the issues of highly polluting potential of POME as well as improper POME treatment of many palm oil industries, extra stringent regulations have been proposed by DOE. With this, the permissible BOD discharge limit of POME has recently been reduced further from $100 \mathrm{mg} / \mathrm{L}$ to 20 $\mathrm{mg} / \mathrm{L}$ [12]. Numerous alternative treatment techniques for POME have been studied by researchers, including aerobic submerged membrane bioreactor [13], anaerobic/aerobic bioreactor [14], activated carbon adsorption and ultrasound cavitation [15,16], membrane process [17,18], advanced oxidation process [19], photocatalytic degradation [9] and electrocoagulation [7]. However, most of these methods are either costly or triggering hostile effects to the environment.

Phytoremediation is defined as a process that utilizes living green plants to remove or control various types of pollutants present in soil, water, sediments and air, such as organic matters, metals, nutrients, pesticides and oil [20]. Over the last few decades, phytoremediation has been widely applied for remediating both contaminated water and shallow soils [21-23]. Phytoremediation has gained keen interest among researchers who are pursuing environmental studies due to its several advantages, which include low operating and maintenance cost, high public acceptance, environmentally friendly and applicable to large remediation area [24]. Various macrophytes have been studied to treat wastewaters, i.e. phytoremediation of textile dyes using Sesuvium portulacastrum, phytoremediation of silver nanoparticle and silver ion contaminated wastewater using Pistia stratiotes, and phytoremediation of textile effluents using Alternanthera philoxeroides [25-27]. Among the various plants organism, water hyacinth (E. crassipes) has gained significant attention due to its superior pollutant uptake capability, fast growth rate, renewability and adaptability to a wide range of wastewater environment [28]. E. crassipes has been proven efficient in absorbing various chemicals in wastewater, including removal of phenol, chromium, cyanide and iron [29-31].

Past studies conducted on phytoremediation of POME using various macrophytes had shown remarkable pollutants removal efficiency, such as Nymphaea sp. [32], Chrysopogon zizanioides L. [33,34], Cyperus alternifolius [35], Lemna minor [36,37], Ipomea aquatica [38], Salvinia molesta [39], Pistia stratiotes [32,40], Leersia oryzoides and Ludwigia peploides [40]. There were some studies presented on the application of E. crassipes on phytoremediation of POME. For instance, Chukwunonso et al. [1] employed E. crassipes in various concentrations of untreated and pre-treated POME for 6 weeks duration with achievement of 50\% reduction of both BOD and COD content. In the pilot-scale treatment of partially digested POME liquor by E. crassipes-based phytoremediation process for 25 days [41], the results showed that E. crassipes successfully removed $87 \%$ of COD, $96 \%$ of BOD, $83 \%$ of ammoniacal nitrogen, $96 \%$ of suspended solids, and $97 \%$ of oil and grease. Another research conducted by Hadiyanto et al. [32] employed E. crassipes for phytoremediation of anaerobically treated POME showed the removal efficiency of $13-31 \%$ for COD, 5-18\% for total nitrogen and 3-50\% for phosphorus. Although those researches evaluated the remediating feasibility 
of pre-treated POME using E. crassipes, the initial pollutants content was still considered too high for E. crassipes, thus unsatisfactory pollutants removal efficiencies were obtained within the studied retention time, hence longer retention time is required to enable the effluent characteristics to comply with the permissible discharge standards. Therefore, this study aims to investigate the feasibility of applying E. crassipes as a potential phytoremediation agent for POME (final discharge) treatment with respect to its ability for removal of COD and $\mathrm{BOD}$, as well as to evaluate the effects of $\mathrm{pH}$, plant:POME ratio and retention time on the pollutants removal efficiency of the phytoremediation system.

\section{Materials and methods}

\subsection{Collection of POME sample}

POME sample was collected from a local palm oil mill at Kota Samarahan, Sarawak. The POME sample was collected from the last ponds of both anaerobic and facultative ponds. The POME sample was stored in a refrigerator at $8{ }^{\circ} \mathrm{C}$ to prevent it from degradation.

\subsection{Effects of $\mathrm{pH}$, plant:POME ratio and retention time}

In this study, the effects of three manipulated variables were investigated, which were the $\mathrm{pH}$, plant:POME ratio and retention time, on the POME characteristics which included biochemical oxygen demand (BOD), chemical oxygen demand (COD) and total suspended solid (TSS). In order to study the effect of $\mathrm{pH}$, the experiments were carried out by manipulating the $\mathrm{pH}$ value of POME sample at fixed plant:POME ratio. The $\mathrm{pH}$ value was adjusted within the $\mathrm{pH}$ range required by the plant to survive. E. crassipes exhibits optimum growth under neutral $\mathrm{pH}$ condition but it is capable to tolerate $\mathrm{pH}$ range of 4-10 [42]. Based on preliminary studies, the E. crassipes used in this study was found to grow and survive well in acidic condition. Therefore, the experiments were conducted by manipulating the $\mathrm{pH}$ value at $\mathrm{pH} \mathrm{4,5,6}$ and 7, for retention time of 21 days and with plant:POME ratio of $1: 20 \mathrm{~kg} / \mathrm{L}$. In order to study the effect of plant:POME ratio, the value was manipulated at 1:20, 1:40, 1:60 and 1:80 kg/L whereas the $\mathrm{pH}$ was controlled at $\mathrm{pH} 6$ and the experiments were conducted for 21 days. In all the experiments conducted, the characteristics of POME were analyzed at $0,7,14$ and 21 days to study the effect of retention time.

\subsection{Characterization of POME}

The POME was characterized for the BOD, COD and TSS in order to determine their correlations with the $\mathrm{pH}$, plant:POME ratio and retention time.

\subsubsection{Biochemical oxygen demand (BOD)}

BOD test attempts to stimulate the natural process of purification of organic matter by oxidation as it occurs in the effluent during which dissolved oxygen (DO) is consumed by microorganism to oxidize the organic matter. BOD is described as the amount of oxygen utilized by microorganism in the aerobic oxidation of the biodegradable organic matter present in the wastewater at specified conditions of temperature and time. BOD value indicates the amount of biodegradable organic content in the effluent [43]. In this study, the dilution method was used in which the direct measurement of DO was made possible by using a DO meter which was speedy and obviated the need for removal of interference. The conditions of the test adopted $30^{\circ} \mathrm{C}$ for 3 days in order to stimulate tropical climatic conditions. 
To perform the BOD test, first an incubation bottle was cleaned with detergent and it was rinsed thoroughly and drained. The bottle was inverted in a water bath to avoid impurities interference between use and cleaning. The POME sample was then measured and diluted. The sample produced at least two different dilutions which were minimum and maximum amount of the sample. The amount of sample to be added to BOD bottles was measured by using Equation (1) and Equation (2). Dilution was carried out by adding dilution water to the sample content in the BOD bottle. Under appropriate dilution condition with incubation period of 3 days, the measured values of residual DO and DO uptake would be $\leq 1 \mathrm{mg} / \mathrm{L}$ and $\leq 2 \mathrm{mg} / \mathrm{L}$, respectively. If the final DO was not passing this limit, the BOD could not be determined [43].

Minimum sample POME, $m L=$
$\frac{\left(\text { Minimum allowable depletion }, \frac{m g}{L}\right) x(\text { Volume of BOD bottle, } m L)}{\text { (Estimated } B O D, m g / L)}$
$\frac{\left(\text { Maximum allowable depletion }, \frac{m g}{L}\right) x(\text { Volume of BOD bottle, } m L)}{(\text { Estimated } B O D, m g / L)}$

Next, the dilution water was prepared by placing the desired quantity of distilled water in a BOD bottle. The volume of water to be placed in the BOD bottle was calculated using Equation (3).

Volume of dilution water, $m L=$ Volume of BOD bottle $-4 \mathrm{~mL}$ - volume of sample water

After that, $1 \mathrm{~mL}$ each of magnesium sulfate solution, calcium chloride solution, phosphate buffer solution, and ferric chloride solution was added to the water. The water was brought to a temperature of $30{ }^{\circ} \mathrm{C}$. The water was then shacked with DO in a partially filled bottle or by aerating with organic-free filtered air. Then, the initial DO value was determined using DO meter. Each sample bottle was then incubated at $30^{\circ} \mathrm{C}$ for 3 days. After 3 days of incubation, the final DO value of each sample bottle was measured. For each bottle which met the $2 \mathrm{mg} / \mathrm{L} \mathrm{DO}$ depletion and $1 \mathrm{mg} / \mathrm{L}$ residual $\mathrm{DO}$ requirements, the $\mathrm{BOD}_{3}$ was calculated. The sample fraction in each bottle was then determined using Equation (4).

$$
\text { Fraction of sample }=\frac{\text { Volume of sample, } m L}{\text { Volume of sample bottle,mL }}
$$

For the case if the bottles were seeded, the $f$ value was measured by using Equation (5).

$$
f=\frac{\text { Fraction of sample for the sample }}{\text { Fraction of sample for the seed control }}
$$

Finally, the $\mathrm{BOD}_{3}$ was calculated for each sample using Equation (6).

$$
B O D_{3}, m g / L=\{(S i-S f)-(B i-B f) f\} \times D
$$

where $S_{i}$ is initial DO of sample (before incubation), $S_{f}$ is final DO of sample (after incubation), $B_{i}$ is initial DO of blank (before incubation), $B_{f}$ is final DO of blank (after incubation), $f$ is fraction due to seed condition, and $D$ is dilution factor. 


\subsubsection{Chemical oxygen demand (COD)}

Chemical oxygen demand (COD) is the measurement of the oxygen requirement to oxidize the organic substances to carbon dioxide, water and ammonia by strong chemical oxidant, such as potassium dichromate $\left(\mathrm{K}_{2} \mathrm{Cr}_{2} \mathrm{O}_{7}\right)$ in the presence of sulphuric acid and silver. The dichromate reflux method is found to be superior among other types of oxidant due to the stronger oxidizing property, capability to a wide array of samples and easy handling [44]. The procedure to measure COD was started adding $50 \mathrm{~mL}$ of POME sample into a refluxing flask. For blank preparation, $50 \mathrm{~mL}$ of distilled water was measured, then 5-7 boiling stones were added to the sample. Next, $1 \mathrm{~g}$ of mercuric sulphate $\left(\mathrm{HgSO}_{4}\right)$ was added to the solution, followed by the adding of $5 \mathrm{~mL}$ of concentrated sulphuric acid $\left(\mathrm{H}_{2} \mathrm{SO}_{4}\right)$ into the solution. Throughout the addition process, the solution was swirled gently to ensure complete dissolve of $\mathrm{HgSO}_{4}$ and to avoid overheating due to the adding of the concentrated $\mathrm{H}_{2} \mathrm{SO}_{4}$. The function of $\mathrm{HgSO}_{4}$ was to bind or complex chlorides. $25 \mathrm{~mL}$ of $0.25 \mathrm{~N}$ potassium dichromate $\left(\mathrm{K}_{2} \mathrm{Cr}_{2} \mathrm{O}_{7}\right)$ was added into the solution and the solution was mixed well. An additional $70 \mathrm{~mL}$ of concentrated $\mathrm{H}_{2} \mathrm{SO}_{4}-\mathrm{HgSO}_{4}$ solution was added while still mixing the solution. After thorough mixing, the flask was attached to the reflux condenser and heat was applied for 2 hours. Refluxing time reduction could be brought under consideration depending on the ease level of oxidizing organic matters. By varying the refluxing periods (15 minutes- 2 hours) and comparing obtained results, the time could be determined. After refluxing process, the apparatus was placed for cooling to room temperature, followed by washing the interior of the condenser and the flask twice with $25 \mathrm{~mL}$ of distilled water. The flask was then removed from the condenser and it was diluted to a final volume of $350 \mathrm{~mL}$ with distilled water. 4 to 5 drops of Ferroin indicator and a magnetic stirring bar was added to the solution. The flask was then placed on a magnetic stirrer and then undergo titration process by using $0.1 \mathrm{~N}$ ferrous ammonium sulphate to the red-brown end point [44]. Equation (7) was used to determine the COD.

$$
C O D, \frac{m g}{L}=\frac{(a-b)(N) x 8000}{\text { Sample size, } m L}
$$

where $a$ is $\mathrm{Fe}\left(\mathrm{NH}_{4}\right)_{2}\left(\mathrm{SO}_{4}\right)_{2}$ used for blank, $\mathrm{mL}, b$ is $\mathrm{Fe}\left(\mathrm{NH}_{4}\right)_{2}\left(\mathrm{SO}_{4}\right)_{2}$ used for sample, $\mathrm{mL}$, and $N$ is normality of FAS titrant $\left(\mathrm{Fe}\left(\mathrm{NH}_{4}\right)_{2}\left(\mathrm{SO}_{4}\right)_{2}\right)$

\subsubsection{Total suspended solid (TSS)}

TSS is the common pollutant which presents in both domestic and industrial wastewaters. Other that turbidity contribution, TSS also causes increase of water temperature due to heat absorption from sunlight and reduction of dissolved oxygen level in water. TSS was determined using filtration technique in which the filter flask was washed and dried prior to be used. The filter paper was rinsed three times by using deionized (DI) water while vacuum was applied through the vacuum filtration unit, then placed in an oven for at least an hour drying process under a temperature of $110 \pm 5^{\circ} \mathrm{C}$ [45]. The weight of the pre-washed and prepped filter paper was recorded. Filtering apparatus was assembled by placing the filter paper in a cleaned Buchner funnel and suction was begun. The filter was wetted with a small quantity of reagent-grade water to get it in position. The contents were shaken, stirred or mixed in a sample container for homogenizing purpose. After that, the desired volume of aliquot was transferred to a clean graduated cylinder. The volume was poured gradually onto the filter paper until the entire aliquot had been filtered. Next, the Buchner funnel was cleaned from any residual sample with DI water, allowing complete drainage between washings, and suction was continued until filtration was complete. The filter was removed from filtration apparatus and transferred to a glass weighing dish as a support. The filters were dried for a minimum of 1 hour at 
$110 \pm 5{ }^{\circ} \mathrm{C}$ in an oven. After drying was completed, the dry filter and residue weight was recorded. Equation (8) was used to determine TSS.

$$
T S S, m g / L=\frac{\frac{(\text { Residue }+ \text { filter }), m g-\text { Filter }, m g}{\text { Sample filtered, } m L} \times 1000 m L}{L}
$$

\section{Results and discussion}

\subsection{Characterization of POME}

The BOD, COD and TSS of the raw POME before phytoremediation was applied were found to be $42.91 \mathrm{mg} / \mathrm{L}, 210.00 \mathrm{mg} / \mathrm{L}$ and $208.67 \mathrm{mg} / \mathrm{L}$, respectively. The $\mathrm{pH}$ of the untreated POME was 8.3. After phytoremediation was applied, the BOD, COD and TSS of the treated POME were determined in order to study the effects of three variables i.e. $\mathrm{pH}$, plant to POME ratio and retention time on the characteristics of POME.

\subsection{Effects of pH and plant to POME ratio on BOD of POME}

Figure 1 shows the effect of $\mathrm{pH}$ on the BOD of POME in 21 days. It could be observed that the E. crassipes was able to reduce BOD level at all the four $\mathrm{pH}$ conditions studied. The BOD of POME decreased dramatically in the first 14 days, and thereafter the BOD reduction rate was slower. Similar findings were reported by Shah et al. [46] that macrophytes (i.e. water hyacinth, water lettuce and duckweed) showed significant BOD removal in the first 10 days but afterwards slower removal rate was attained. This phenomenon was also consistent with the study of Dinges [47], which reported that the substantial reduction of mean BOD through a pilot scale treatment system that composed primarily of water hyacinth pond units receiving stabilizing pond effluent from the Willianson Creek Waste Water Treatment Plant at Austin, Texas. The pilot scale treatment system occupied a surface area of 0.14 acres and operated with 5 days of retention time, successfully achieved significant reduction in both mean values of $\mathrm{BOD}_{5}$ and $\mathrm{BOD}_{10}$, with satisfied removal efficiency of $81.58 \%$ and $81.48 \%$, respectively. Figure 1 shows that the E. crassipes was able to reduce the BOD from a level of approximately 40 to $42 \mathrm{mg} / \mathrm{L}$ to a level of approximately 20 to $23 \mathrm{mg} / \mathrm{L}$ after 7 days for all samples. After 21 days, the POME samples started to be dehydrated due to the POME uptake by the plants and natural vaporization, causing the plants to stop growing and eventually faded. The decomposition of plants generated organic wastes which resulted in the increased oxygen demand required by microorganisms such as bacteria to decompose the wastes [48]. The control experiment conducted in this study showed BOD reduction of $11.44 \%$ after 7 days exposure. In a laboratory scale investigation conducted by Wolverton et al. [49], the results showed that higher $\mathrm{BOD}_{5}$ removal efficiency was obtained for both raw sewage and secondary effluent after 7 days of treatment process by using $E$. crassipes, which accounted as $97 \%$ and $77 \%$ respectively. However, the control treatment system without $E$. crassipes achieved comparatively lower $\mathrm{BOD}_{5}$ reduction, that is, $61 \%$ for the raw sewage while $6 \%$ for the secondary effluent. This phenomenon occurred because the extensive roots network of $E$. crassipes provide large surface area for inhabitation and growth of microbes that could facilitate the plants to degrade the organic substances present in surrounding aquatic environment [50]. The findings showed that the plants were able to reduce the BOD level in 7 days with sufficient supply of POME to support the plants' growth. In this study, the BOD reduction was the highest at $\mathrm{pH} 4$, in which the BOD was reduced to $3.1 \mathrm{mg} / \mathrm{L}$ after 21 days of treatment, which was equivalent to $92.78 \%$ reduction. According to Abou-Elela and Hellal [51], high BOD removal efficiency in a wetland system could be explained by both physical and microbial means: i) rapid deposition and filtration of settleable organic matters; ii) aerobic and anaerobic degradation of organic matters by heterotrophic

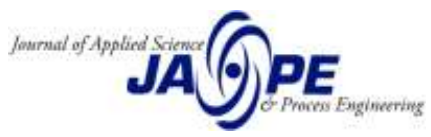


bacteria. From the results obtained, it could be concluded that the E. crassipes was a feasible macrophyte to reduce the BOD level in duration of approximately 7 days, to meet the BOD discharge limit of $20 \mathrm{mg} / \mathrm{L}$ as permitted by the Department of Environment, Malaysia.

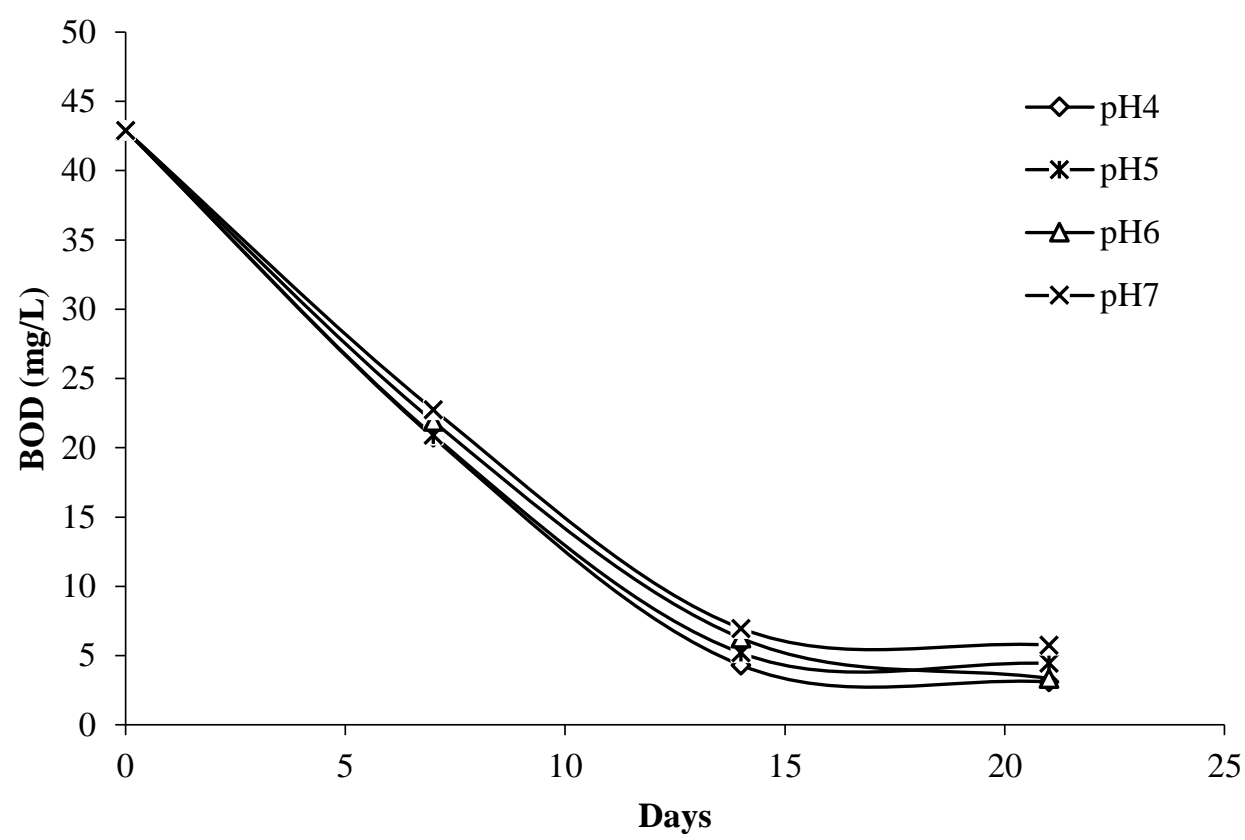

Figure 1. Effect of pH on BOD of POME in 21 days.

Figure 2 shows the effect of plant to POME ratio on the BOD of POME in 21 days. It could be observed that the E. crassipes had high potential to grow at various plant to POME ratios, and was able to reduce the BOD level at all the four ratios studied by resulting in more than $80 \%$ of BOD reduction. The highest $\mathrm{BOD}$ reduction of $91.9 \%$ was achieved at 1:20 plant to POME ratio after 21 days of treatment. As comparison, Darajeh et al. [33] conducted study on POME treatment using Chrysopogon zizanioides (L.) and obtained maximum BOD removal of $92.8 \%$ (from $50 \mathrm{mg} / \mathrm{L}$ to 3.6 $\mathrm{mg} / \mathrm{L}$ ) after 14 days of retention time. During phytoremediation process, daily photosynthetic activity carried out by plants could be beneficial to reduce the content of dissolved carbon dioxide by conversion into dissolved oxygen in water, thus causing the aerobic microbes to break down organic material in the wastewater [52]. This phenomenon then caused the BOD level to be reduced from day to day. Lower plant to POME ratio gave higher BOD reduction mainly because at high plant densities, the microbes' activities decreased due to poor utilization of solar energy caused by self shading of the plants [53]. Besides, there might be high competency of plant nutrients for growth when the plant densities were higher. 


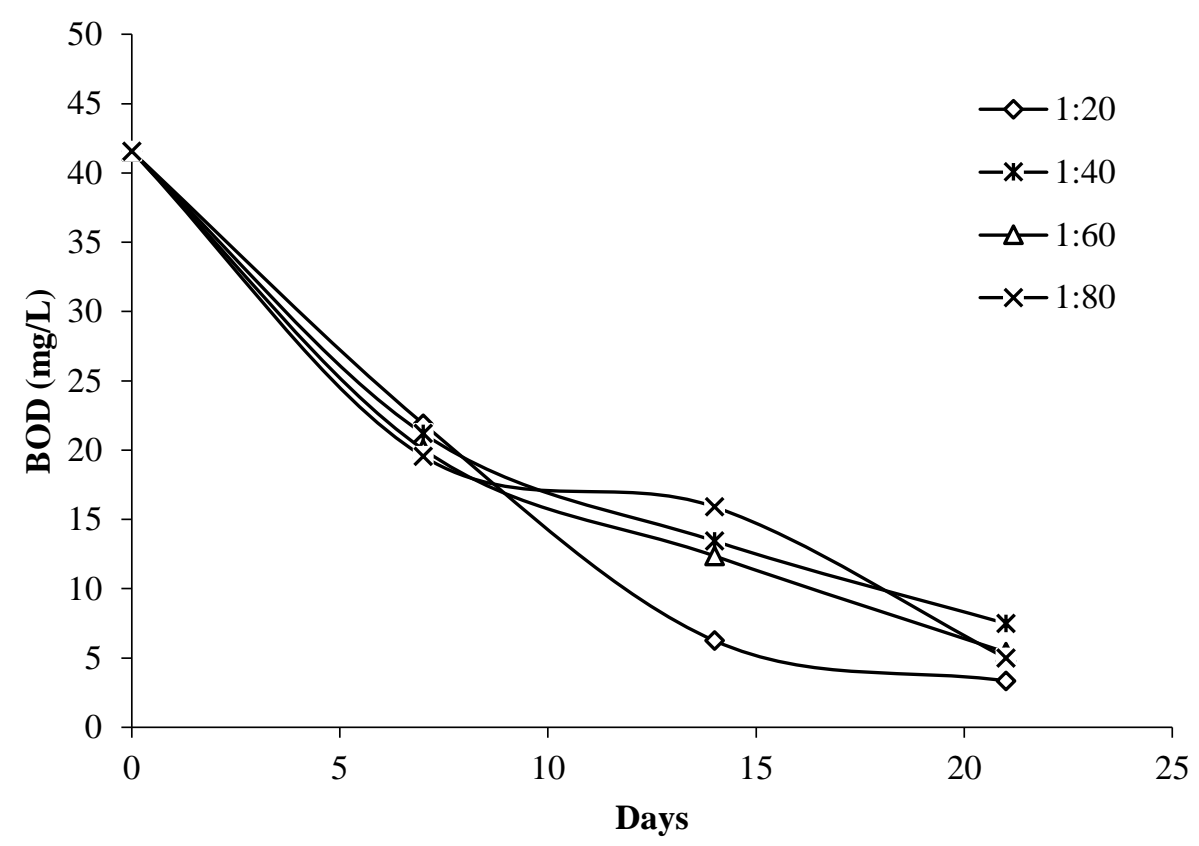

Figure 2. Effect of plant to POME ratio on BOD of POME in 21 days.

\subsection{Effects of $\mathrm{pH}$ and plant to POME ratio on COD of POME}

Figure 3 shows the effect of $\mathrm{pH}$ on the COD of POME in 21 days. The COD level was found to decrease in the first 7 days at all the $\mathrm{pH}$ conditions studied. After 7 days of exposure, the COD increased again for POME at $\mathrm{pH} \mathrm{4,5}$ and 7. The highest COD reduction in the POME was achieved at pH 6 within 14 days, which resulted in COD of $157 \mathrm{mg} / \mathrm{L}$, equivalent to $25.24 \%$ removal. The COD removal mechanism in a free-floating phytoremediation system was due to the synergistical relationship among the macrophytes and the rhizosphere microorganisms, at which macrophytes provided growth medium and aerobic environment at the root zone while aerobic bacteria carried out microbial activity to degrade organic matter $[1,32,34,35]$. However, after 14 days, the COD increased to $201 \mathrm{mg} / \mathrm{L}$ at day 21. The results agreed with Snow and Ghaly [54] which found that the COD reduction decreased as retention time was increased in 5 days duration. From the study conducted by Koottatep and Polprasert [55], 71\% reduction of COD was obtained within 1 day and $83 \%$ reduction of COD in 5 days using constructed wetlands. Jing et al. [56] reported 13 to $51 \%$ of COD removal efficiency in river water using pilot-scale constructed wetlands. This suggested that the condition of the wastewater and type of macrophytes used in the phytoremediation greatly influenced the treatment efficiency. According to Tang and Lu [57], E. crassipes could grow in pre-treated oil-refinery wastewater. However, oil-refinery wastewater with COD concentration that was higher than $131 \mathrm{mg} / \mathrm{L}$ brought long-term toxic effect towards $E$. crassipes. The results obtained from the numerical investigation evaluated that the applicable operating range of COD concentration for E. crassipes to treat oil-refinery wastewater was 65 to $131 \mathrm{mg} / \mathrm{L}$. This could be the possible explanation for the relatively low percentage of COD reduction obtained in this study, mainly because the POME wastewater contained some amount of oil and grease with relatively high initial COD. The overall results were consistent with the findings reported in the literature which stated that E. crassipes was able to take up chemical in wastewater and absorb organic contaminants and nutrients from the water column [58]. 


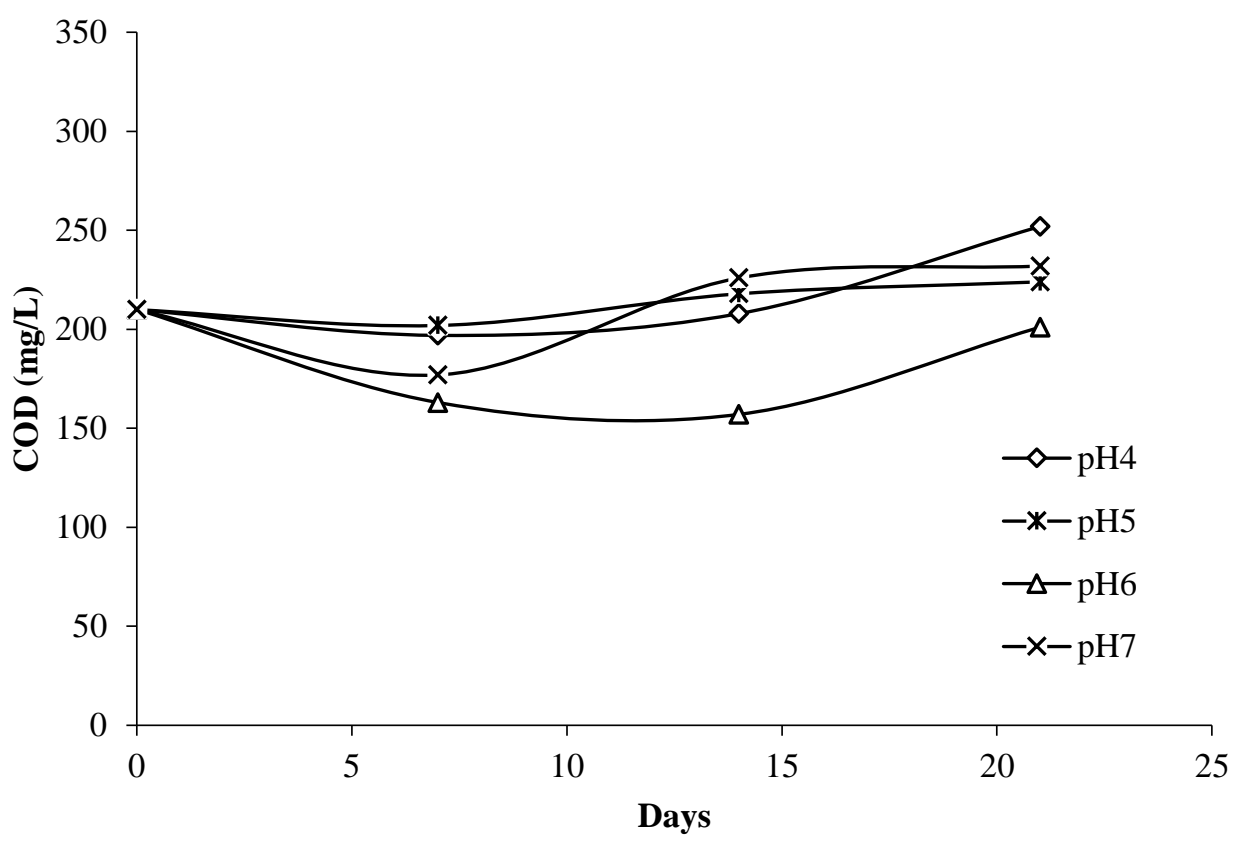

Figure 3. Effect of $\mathrm{pH}$ on COD of POME in 21 days.

Figure 4 shows the effect of plant to POME ratio on the COD of POME in 21 days. It was found that the highest COD reduction was achieved after 14 days of treatment for all the ratios studied, after which the COD level increased gradually. Plant to POME ratio of 1:20 was the best condition to remove COD, which showed $25.2 \%$ of COD reduction. This result was consistent with Snow and Ghaly [54] which found that the water hyacinth and water lettuce were able to decrease the COD in wastewater as retention time was increased in 5 days duration, however the reduction was not significantly influenced by the retention time. Kulatillake and Yapa [59] successfully achieved COD reduction of $80 \%$ in rubber factory effluents by using water hyacinth.

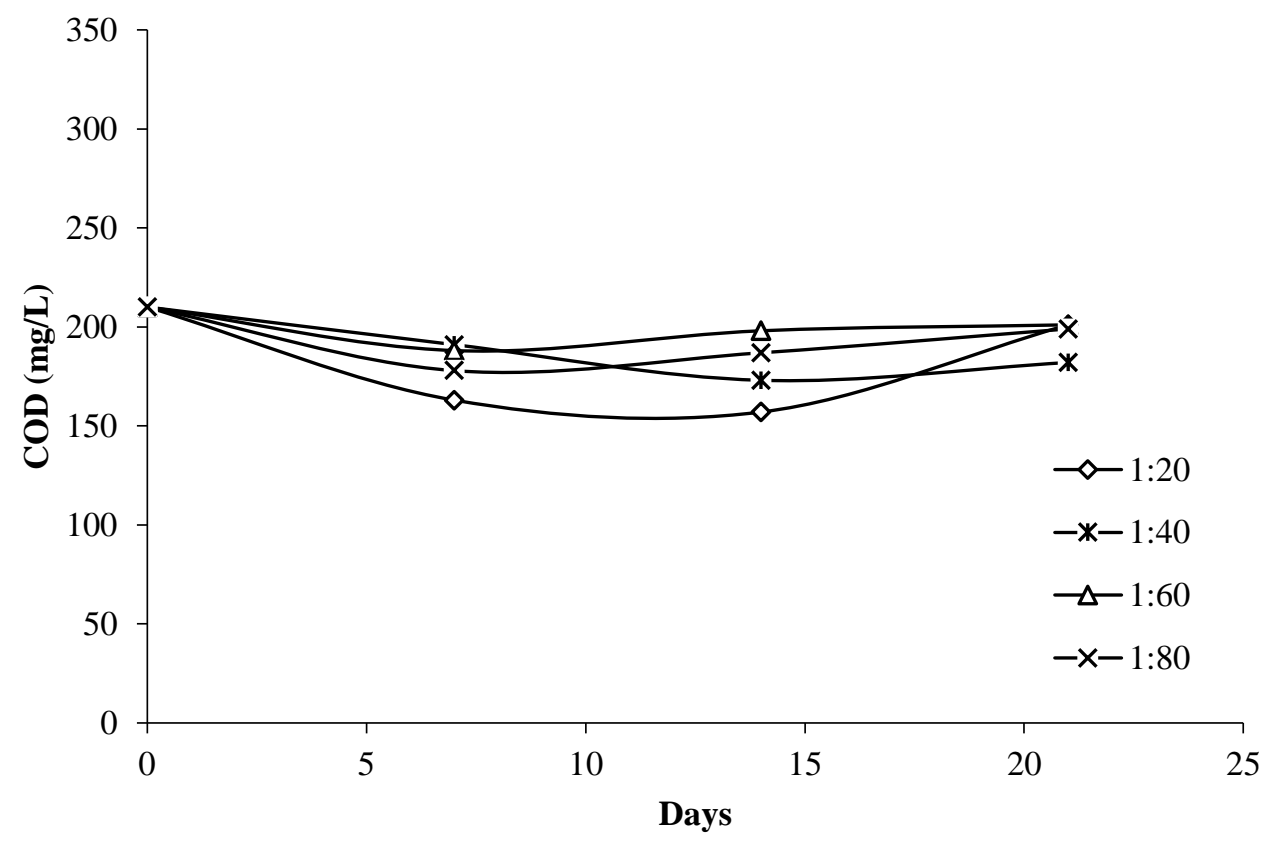

Figure 4. Effect of plant to POME ratio on COD of POME in 21 days. 


\subsection{Effects of pH and plant to POME ratio on TSS of POME}

Figure 5 shows the effect of $\mathrm{pH}$ on the TSS of POME in 21 days. It was found that the amount of TSS present in all the four samples increased gradually from day 0 to day 21 . TSS increased because of the plants which grew from day to day by replacing the old stem with new stem in the basin. As the experiments were carried out in a batch system, this therefore caused the basin to contain more suspended particles accumulated at the bottom of the basin, leading to increased TSS values. Regular harvesting of plants is therefore recommended as the control measure by maintaining the plant densities to prevent drastic TSS increment. It could be observed that the TSS of POME was not influenced much by the $\mathrm{pH}$. This was because the removal of TSS was depending on retention time since it was a physical separation process rather than microbiological [60].

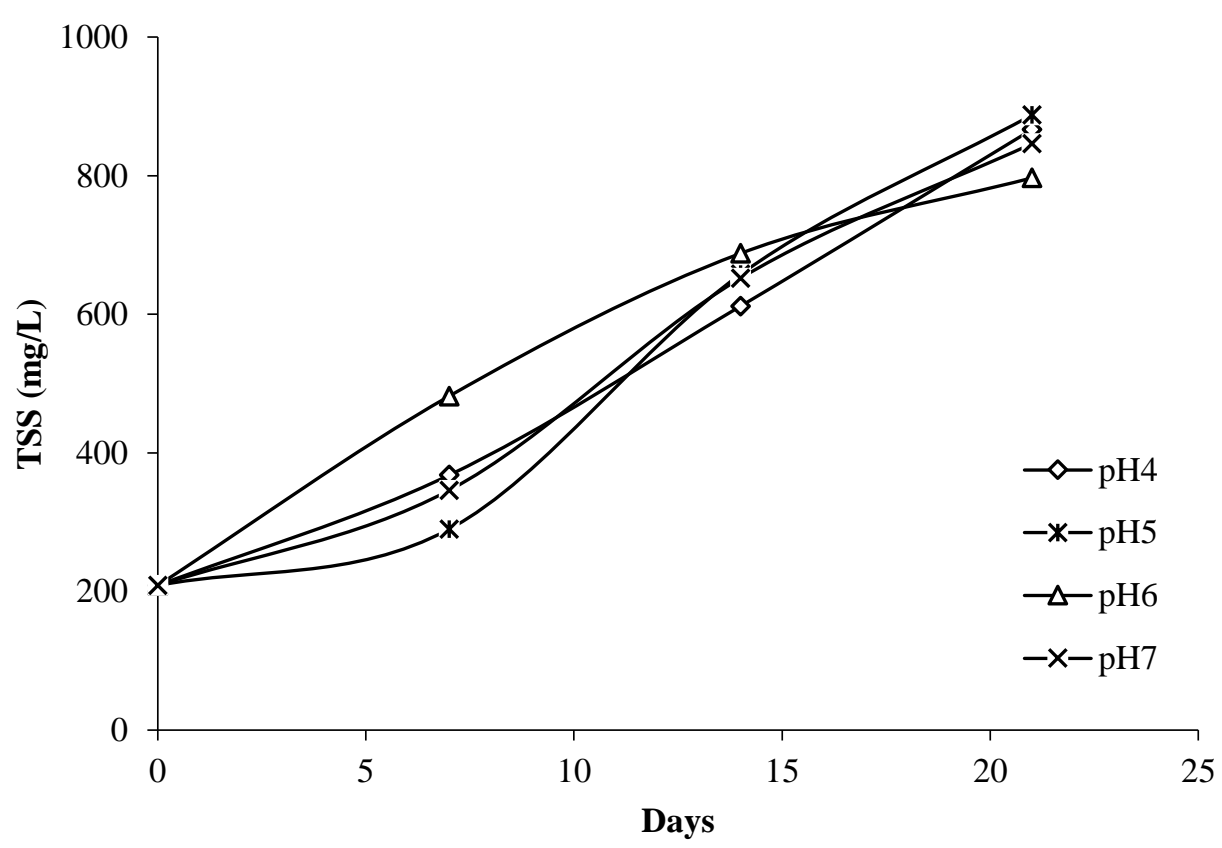

Figure 5. Effect of $\mathrm{pH}$ on TSS of POME in 21 days.

Figure 6 shows the effect of plant to POME ratio on the TSS of POME in 21 days. Similar to the effect of $\mathrm{pH}$, it was found that the amount of TSS present in all the four samples increased gradually from day 0 to day 21 . The TSS of POME might be affected by the roots or leaves of the plants that decomposed during the treatment. The sample with higher plant densities showed higher TSS values possibly due to more wastes were produced after the decomposition of the plants. From the study on POME treatment process using Salvinia molesta conducted by Ng and Chan [39], the initial TSS content of $9 \mathrm{mg} / \mathrm{L}$ was found to decrease slightly after 4 days of retention time, however the TSS values experienced a drastic increment until retention time of 16 days. In this study, phytoremediation was placed at outdoor condition and the sunlight availability contributed to the formation of filamentous algae. Other than the growth of algae, accumulation of biomass content especially microorganisms in wastewater along the phytoremediation process might also cause the increase of TSS values [39]. 


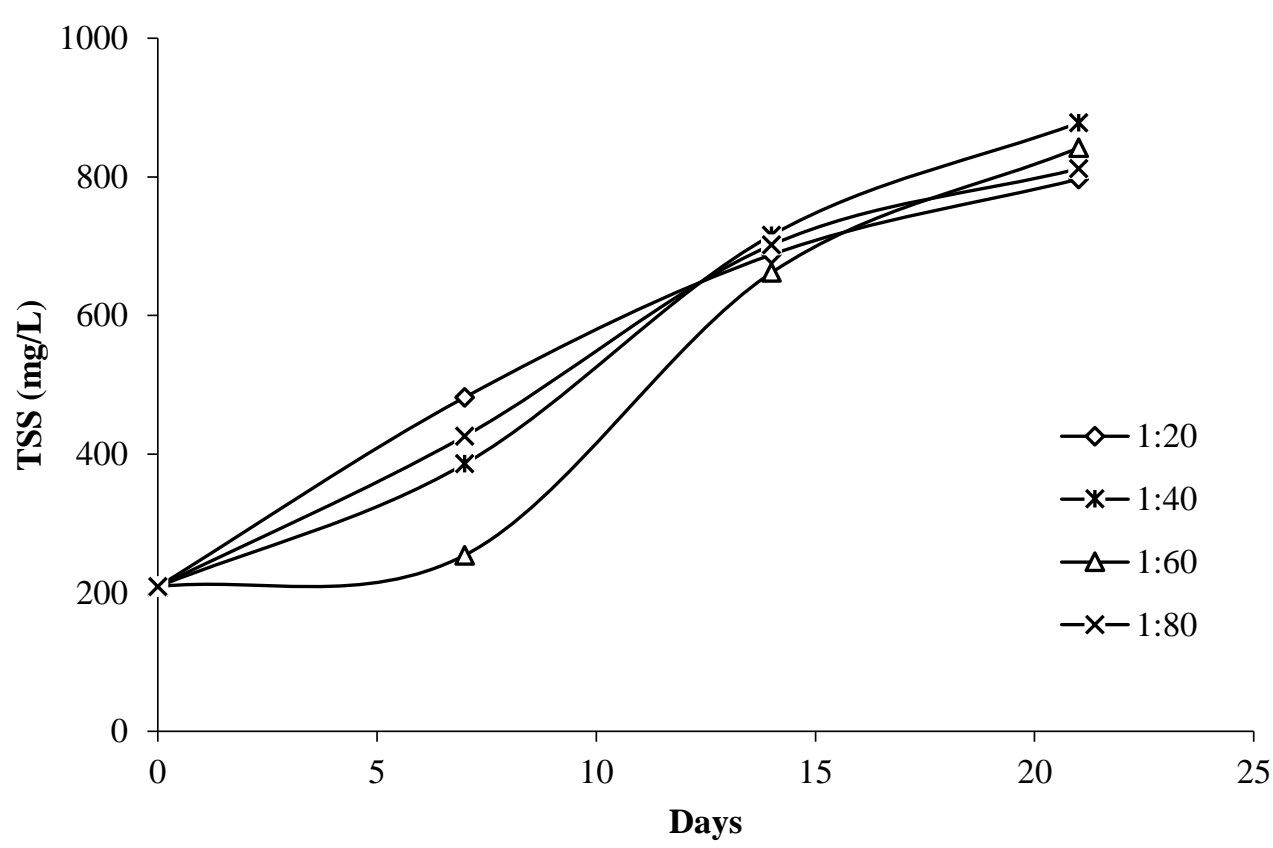

Figure 6. Effect of plant to POME ratio on TSS of POME in 21 days.

\section{Conclusions}

The three parameters studied ( $\mathrm{pH}$, plant to POME ratio and retention time) were found to show significant effects on the BOD and COD reduction in POME. The E. crassipes was able to reduce BOD dramatically from day 0 to day 14 , and thereafter the BOD reduction rate was slower. The BOD was significantly reduced from approximately $42.91 \mathrm{mg} / \mathrm{L}$ to a level of approximately $20-23 \mathrm{mg} / \mathrm{L}$ after 7 days of treatment for all the conditions studied, which complied with the discharge standards of $20 \mathrm{mg} / \mathrm{L}$ imposed by DOE. The highest COD reduction was observed at condition of $\mathrm{pH} 6$ and 1:20 plant to POME ratio, which resulted in $25.24 \%$ of COD removal after 14 days of treatment. TSS of POME was found to increase gradually from $200 \mathrm{mg} / \mathrm{L}$ to around $900 \mathrm{mg} / \mathrm{L}$ after 21 days of treatment at all conditions studied. Regular harvesting of plants is therefore recommended as the control measure by maintaining the plant densities to prevent drastic TSS increment. From this research, it could be concluded that $E$. crassipes had high potential to decrease the BOD and COD content in POME within 7 days of treatment. This noteworthy accomplishment in gaining satisfactory results in short duration would indicate a significant breakthrough since it could overcome the slowness issue of conventional biological treatment using ponding system that requires a minimum of 2 to 3 months of retention time. Phytoremediation of POME has been proven to be an environmental friendly and cost effective treatment process in which minimal maintenance cost is required. The effectiveness of phytoremediation technique for POME treatment is therefore recommended as a promising alternative solution to this industrial wastewater.

\section{Acknowledgements}

The authors acknowledge the research grants provided by Universiti Malaysia Sarawak under Dana Pembudayaan Penyelidikan RAGS/TK/05(2)/941/2012(42) and Fundamental Research Grant Scheme FRGS/TK02(05)/1305/2015(22) funded by Ministry of Education Malaysia. 


\section{References}

[1] Chukwunonso, O. I., Fauziah, S. H., Redzwan, G. (2014). The Utilization of Water Hyacinth (Eichhornia Crassipes) as Aquatic Macrophage Treatment System (AMATS) in Phytoremediation for Palm Oil Mill Effluent (POME), International Journal of Sciences: Basic and Applied Research, Vol. 13, 31-47.

[2] Ding, G. T., Yaakob, Z., Takriff, M. S., Salihon, J., Abd Rahaman, M. S. (2016). Biomass Production and Nutrients Removal by a Newly-Isolated Microalgal Strain Chlamydomonas Sp in Palm Oil Mill Effluent (POME), International Journal of Hydrogen Energy, Vol. 41, 4888-4895.

[3] Bello, M. M. and Abdul Raman, A. A. (2017). Trend and Current Practices of Palm Oil Mill Effluent Polishing: Application of Advanced Oxidation Processes and Their Future Perspectives, Journal of Environmental Management, Vol. 198, 170-182.

[4] Ahmad, A. L., Chan, C. Y., Shukor, S. R. A., Mashitah, M. D. (2010). Optimization of Carotene Recovery from Extracted Oil of POME by Adsorption Chromatography Using Response Surface Methodology, Separation and Purification Technology, Vol. 73, 279-285.

[5] Zinatizadeh, A. A. L., Mohamed, A. R., Mashitah, M. D., Abdullah, A. Z., Najafpour, G. D. (2006). Pretreated Palm Oil Mill Effluent (POME) Digestion in an Up-Flow Anaerobic Sludge Fixed Film Bioreactor: A Comparative Study, International Journal of Engineering: Transactions B (Applications), Vol. 19, 1-9.

[6] Latif, A. I., Suzylawati, I., Norliza, I., Bhatia, S. (2003). Removal of Suspended Solids and Residual Oil from Palm Oil Mill Effluent, Journal of Chemical Technology and Biotechnology, Vol. 78, 971-978.

[7] Nasrullah, M., Singh, L., Mohamad Z., Norsita, S., Krishnan, S., Wahida, N., Zularisam, A. W. (2017). Treatment of Palm Oil Mill Effluent by Electrocoagulation with Presence of Hydrogen Peroxide as Oxidizing Agent and Polialuminum Chloride as Coagulant-Aid, Water Resources and Industry, Vol. 17, 7 10.

[8] Ma, A. N. (2000). Environmental Management for the Palm Oil Industry, Palm Oil Developments, Vol. 30, $1-10$.

[9] Ng, K. H., Lee, C. H., Khan, M. R., Cheng, C. K. (2016). Photocatalytic Degradation of Recalcitrant POME Waste by Using Silver Doped Titania: Photokinetics and Scavenging Studies, Chemical Engineering Journal, Vol. 286, 282-290.

[10] Schuchardt, F., Wulfert, K., Darnoko, D., Herawan, T. (2008). Effect of New Palm Oil Mill Processes on the EFB and POME Utilization, Journal of Oil Palm Research, Vol. Special Issue 2008, 115-126.

[11] Wu, J., Ma, X. Z., Wang, Z. (2010). Provincial Emission Permits Quota Allocations in China, Quaternary Science, Vol. 30, No. 3, 481-488.

[12] Tabassum, S., Zhang, Y., Zhang, Z. (2015). An Integrated Method for Palm Oil Mill Effluent (POME) Treatment for Achieving Zero Liquid Discharge - A Pilot Study, Journal of Cleaner Production, Vol. 95, 148-155.

[13] Yuniarto, A., Noor, Z. Z., Ujang, Z., Olsson, G., Aris, A., Hadibarata, T. (2013). Bio-Fouling Reducers for Improving the Performance of an Aerobic Submerged Membrane Bioreactor Treating Palm Oil Mill Effluent, Desalination, Vol. 316, 146-153.

[14] Chan, Y. J., Chong, M. F., Law, C. L. (2012). An Integrated Anaerobic-Aerobic Bioreactor (IAAB) for the Treatment of Palm Oil Mill Effluent (POME): Start-Up and Steady State Performance, Process Biochemistry, Vol. 47, No. 3, 485-495.

[15] Parthasarathy, S., Mohammed, R. R., Chong, M. F., Gomes, R. L., Manickam, S. (2016). A Novel Hybrid Approach of Activated Carbon and Ultrasound Cavitation for the Intensification of Palm Oil Mill Effluent (POME) Polishing, Journal of Cleaner Production, Vol. 112, 1218-1226.

[16] Said, M., Hasan, H. A., Tusirin, M., Nor, M. (2016). Removal of COD, TSS and Colour from Palm Oil Mill Effluent (POME) Using Montmorillonite, Desalination and Water Treatment, Vol. 57, 10490-10497. 
[17] Ahmed, Y., Yaakob, Z., Akhtar, P., Sopian, K. (2015). Production Of Biogas And Performance Evaluation Of Existing Treatment Processes In Palm Oil Mill Effluent (POME), Renewable and Sustainable Energy Reviews, Vol. 42, 1260-1278.

[18] Ho, K. C., Teow, Y. H., Ang, W. L., Mohammad, A. W. (2017). Novel GO/OMWCNTs Mixed-Matrix Membrane with Enhanced Antifouling Property for Palm Oil Mill Effluent Treatment, Separation and Purification Technology, Vol. 177, 337-349.

[19] Saeed, M. O., Azizli, K. A. M., Isa, M. H., Ezechi, E. H. (2016). Treatment of POME Using Fenton Oxidation Process: Removal Efficiency, Optimization, and Acidity Condition, Desalination and Water Treatment, Vol. 3994, 1-10.

[20] McCutcheon, S. C. and Jorgensen, S. E. (2008). Phytoremediation, S. E. Jorgensen, B. Fath, (Eds.), Encyclopedia of Ecology, Elsevier Science BV, Amsterdam, Netherlands.

[21] Lettinga, G. (1995). Anaerobic Digestion and Wastewater Treatment Systems, Antonie van Leeuwenhoek, Vol. 67, 3-28.

[22] Salt, D. E., Kato, N., Kramer, U., Smith, R. D., Raskin, I. (2000). The Role of Root Exudates in Nickel Hyperaccumulation and Tolerance in Accumulator and Non Accumulator Species of Thlaspi, N. Terry, G. Banuelos, (Eds.), Phytoremediation of Contaminated Soil and Water, CRS Press LLC, London.

[23] Miretzky, P., Saralegui, A., Cirelli, A. F. (2004). Aquatic Macrophytes Potential for the Simultaneous Removal of Heavy Metals (Buenos Aires, Argentina), Chemosphere, Vol. 57, 997-1005.

[24] Environmental Protection Agency (EPA). (2001). A Citizen's Guide to Phytoremediation, EPA 542-F-01002.

[25] Hanks, N. A., Caruso, J. A., Zhang, P. (2015). Assessing Pistia stratiotes for Phytoremediation of Silver Nanoparticles and Ag(I) Contaminated Waters, Journal of Environmental Management, Vol. 164, 41-45.

[26] Lokhande, V. H., Kudale, S., Nikalje, G., Desai, N., Suprasanna, P. (2015). Hairy Root Induction and Phytoremediation of Textile Dye, Reactive Green 19A-HE4BD, in a Halophyte, Sesuvium portulacastrum (L.) L., Biotechnology Reports, Vol. 8, 56-63.

[27] Rane, N. R., Chandanshive, V. V., Watharkar A. D., Khandare, R. V., Patil, T. S., Pawar, P. K., Govindwar, S. P. (2015). Phytoremediation of Sulfonated Remazol Red Dye and Textile Effluents by Alternanthera philoxeroides: An Anatomical, Enzymatic and Pilot Scale Study, Water Research, Vol. 83, 271-281.

[28] Rezania, S., Ponraj, M., Talaiekhozani A., Mohamad, S. E., Md Din, M. F., Taib, S. M., Sabbagh, F., Md Sairan, F. (2015). Perspectives of Phytoremediation Using Water Hyacinth for Removal of Heavy Metals, Organic and Inorganic Pollutants in Wastewater, Journal of Environmental Management, Vol. 163, 125133.

[29] Ebel, M., Evangelou, M. W. H., Schaeffer, A. (2007). Cyanide Phytoremediation by Water Hyacinths (Eichhornia crassipes), Chemosphere, Vol. 66, No. 5, 816-823.

[30] Jayaweera, M. W., Kasturiarachchi, J. C., Kularatne, R. K. A., Wijeyekoon, S. L. J. (2008). Contribution of Water Hyacinth (Eichhornia crassipes (Mart.) Solms) Grown under Different Nutrient Conditions to Feremoval Mechanisms in Constructed Wetlands, Journal of Environmental Management, Vol. 87, No. 3, 450-460.

[31] Gupta, A. and Balomajumder, C. (2015). Removal of Cr(VI) and Phenol Using Water Hyacinth from Single and Binary Solution in the Artificial Photosynthesis Chamber, Journal of Water Process Engineering, Vol. 7, 74-82.

[32] Hadiyanto, H., Christwarda, M., Soetrisnanto, D. (2013). Phytoremediation of Palm Oil Mill Effluent (POME) by Aquatic Plants and Microalgae for Biomass Production, Journal of Environmental Science and Technology, Vol. 6, 79-90.

[33] Darajeh, N., Idris, A., Masoumi, H. R. F., Nourani, A., Truong, P., Rezania, S. (2017). Phytoremediation of Palm Oil Mill Secondary Effluent (POMSE) by Chrysopogon zizanioides (L.) Using Artificial Neural Network, International Journal of Phytoremediation, Vol. 19, No. 5, 413-424. 
[34] Darajeh, N., Idris, A., Masoumi, H. R. F., Nourani, A., Truong, P., Sairi, N. A. (2016). Modeling BOD and COD Removal from Palm Oil Mill Secondary Effluent in Floating Wetland by Chrysopogon zizanioides (L.) Using Response Surface Methodology, Journal of Environmental Management, Vol. 181, 343-352.

[35] Sa'at, S. K. M., Zaman, N. Q., Yusoff, S. M., Ismail, H. A. (2017). Investigation of the Potential of Cyperus alternifolius in the Phytoremediation of Palm oil Mill effluent., in Proceedings of the International Conference of Global Network for Innovative Technology and AWAM International Conference in Civil Engineering (IGNITE-AICCE'17), 040009-1-040009-7.

[36] Kamyab, H., Chelliapan, S., Din M. F. M., Shahbazian-Yassar, R., Rezania, S. Hadiyanto, H., Soetrisnanto, D., Christwardhana, M. (2014). Phytoremediation of Palm Oil Mill effluent by Using Pistia stratiotes Plant and Algae Spirulina sp for Biomass Production, International Journal of Engineering: Transactions C (Aspects), Vol. 27, 1809-1814.

[37] Kumar, A. and Azimi, M. (2017). Evaluation of Lemna minor and Chlamydomonas to Treat Palm Oil Mill Effluent and Fertilizer Production, Journal of Water Process Engineering, Vol. 17, 229-236.

[38] Farraji, H., Zaman, N. Q., Sa'at, S. K. M., Dashtia, A. F. (2017). Phytoremediation of Suspended Solids and Turbidity of Palm Oil Mill Effluent (POME) by Ipomea Aquatica, Engineering Heritage Journal, Vol. 1, No. 1, 36-40.

[39] Ng, Y. S. and Chan, D. J. C. (2017). Wastewater Phytoremediation by Salvinia molesta, Journal of Water Process Engineering, Vol. 15, 107-115.

[40] Hamzah, M. F., Yusof, N., Alimon, H. (2016). Microbial Assisted Phytoremediation of Palm Oil Final Discharge (POMFD) Wastewater, Journal of Oil Palm Research, Vol. 28, 320-330.

[41] John, C. K. (1984). Treatment of Agro-Industrial Wastes Using Water Hyacinth, Water Science and Technology, Vol. 17, 781-790.

[42] Center, T. D., Hill, M. P., Cordo, H., Julien, M. H. (2002). Water Hyacinth, R. G. van Driesche, S. Lyon, B. Blossey, M. S. Hoddle, R. Reardon (Eds.), Biological Control of Invasive Plants in the Eastern United States, Morgantown, WV: USDA Forest Service, 41-64.

[43] American Public Health Association, American Water Works Association, and Water Environment Federation (APHA/AWWA/WEF). (1998). Standard Methods for the Examination of Water and Wastewater, American Public Health Association, Washington, D.C.

[44] Azbar, N. and Yonar, T. (2004). Comparative Evaluation of a Laboratory and Full-Scale Treatment Alternatives for the Vegetable Oil Refining Industry Wastewater (VORW), Process Biochemistry, Vol. 39, 869-875.

[45] Prego, R., Boi, P., García, A. C. (2008). The Contribution of Total Suspended Solids to the Bay of Biscay by Cantabrian Rivers (northern coast of the Iberian Peninsula), Journal of Marine Systems, vol. 72, 342349.

[46] Shah, M., Hashmi, H. N., Ali, A., Ghumman, A. R. (2014). Performance Assessment of Aquatic Macrophytes for Treatment of Municipal Wastewater, Journal of Environmental Health Science and Engineering, Vol. 12, No. 1, 106.

[47] Dinges, W. R. (1976). Who Says Sewage Treatment Plants Have to be Ugly?, Water Wastes Engineering, Vol. 13, 20-23.

[48] Saeed, S. M. and Al-Nagaawy, A. M. A. (2013). Impact of Water Hyacinth (Eichhornia crassipes) on Physico-Chemical Properties of Water, Phytoplankton Biomass and Nile Tilapia Production in Earthen Ponds, Journal of the Arabian Aquaculure Society, Vol. 8, 249-262.

[49] Wolverton, B. C., Barlow, R. M., Mcdonald, R. C. (1976). Application of Vascular Aquatic Plants for Pollution Removal, Energy and Food Production in a Biological System, J. Tourbier and Jr. R. W. Pierson, (Eds.), Biological Control of Water Pollution, Univ. Pennsylvania, 141-150.

[50] Polprasert, C. and Khatiwada, N. R. (1998). An Integrated Kinetic Model for Water Hyacinth Ponds used for Wastewater Treatment, Water Research, Vol. 32, 179-185. 
[51] Abou-Elela, S. I. and Hellal, M. S. (2012). Municipal Wastewater Treatment Using Vertical Flow Constructed Wetlands Planted with Canna, Phragmites and Cyprus, Ecological Engineering, Vol. 47, 209213.

[52] Reddy, K. R. (1981). Diel Variations in Physio-Chemical Parameters of Water in Selected Aquatic Systems, Hydrobiologia, Vol. 85, 201-207.

[53] Akinbile, C. O. and Yusoff, M. S. (2012). Water Hyacinth (Eichhornia crassipes) and Lettuce (Pistia stratiotes) Effectiveness in Aquaculture Wastewater Treatment in Malaysia, International Journal of Phytoremediation, Vol. 14, 201-211.

[54] Snow, A. M. and Ghaly, A. E. (2008). A Comparative Study of the Purification of Aquaculture Wastewater Using Water Hyacinth, Water Lettuce and Parrot's Feather, American Journal of Applied Sciences, Vol. 5, 440-453.

[55] Koottatep, T. and Polprasert, C. (1997). Role of Plant Uptake on Nitrogen Removal in Constructed Wetlands Located in the Tropics, Water Science and Technology, Vol. 36, 1-8.

[56] Jing, S. R., Lin, Y. F., Lee, D. Y., Wang, T. W. (2001). Nutrient Removal from Polluted River Water by Using Constructed Wetlands, Bioresource Technology, Vol. 76, 131-135.

[57] Tang, S. -Y. and Lu, X. -W. (1993). The Use of Eichhornia Crassipes to Cleanse Oil-Refinery Wastewater in China, Ecological Engineering, Vol. 2, 243-251.

[58] Aoi, T. and Hayashi, T. (1996). Nutrient Removal by Water Lettuce (Pistia stratiotes), Water Science and Technology, Vol. 34, 407-412.

[59] Kulatillake, N. and Yapa, P. A. J. (1984). A Study on the Use of Water Hyacinth in Rubber Effluent Treatment Systems, in Proceedings of Malaysian Chemical Congress, Kuala Lumpur.

[60] Manios, T., Stentiford, E. I., Miller, P. (2003). Removal of Total Suspended Solids from Wastewater in Constructed Horizontal Flow Subsurface Wetlands, Journal of Environmental Science and Health, Part A: Toxic/Hazardous Substances and Environmental Engineering, Vol. 38, 1073-1085. 